\title{
Gigantic ascending aortic aneurysm with consequently severe aortic regurgitation and dilatated cardiomyopathy: a case report
}

\author{
(i) Ivana Lukić', \\ (D) Marul Ivandić', \\ (D) Sandra Makarovićci,2* \\ ${ }^{1}$ University Hospital Centre \\ Osijek, Osijek, Croatia \\ 2University Josip Juraj \\ Strossmayer Osijek, Faculty \\ of Medicine, Osijek, Croatia
}

\author{
KEYWORDS: aortic aneurysm, echocardiography, cardiac surgery \\ CITATION: Cardiol Croat. 2019;14(3-4):86. | https://doi.org/10.15836/ccar2019.86
}

*ADDRESS FOR CORRESPONDENCE: Sandra Makarović, Klinički bolnički centar Osijek, Ul. Josipa Huttlera 4, HR31000, 0sijek, Croatia. / Phone: +385-31-511-511 / E-mail: sandramakarovic@yahoo.com

ORCID: Ivana Lukić, https://orcid.org/0000-0001-9832-6700 • Marul Ivandić, https://orcid.org/0000-0003-0716-5388 Sandra Makarović, https://orcid.org/0000-0002-7487-1189

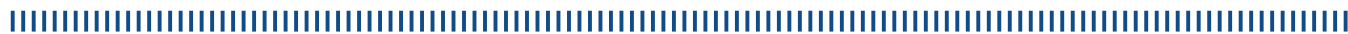

Introduction: An ascending aortic aneurysm is defined as localized dilatation of aorta. We classify thoracic aortic aneurysms into aortic root or ascending aortic aneurysms (most common, $\approx 60 \%$ ), followed by descending aortic aneurysms ( $\approx 35 \%)$ and aneurysms of aortic arch $(<10 \%)$. It is a disease of insidious progression which is initially mostly asymptomatic. Clinical presentation depends on the size and rate of growth of the disease itself, which sometimes makes it difficult to recognize until first complications arise, and it is unfortunately in many cases initially presented by aortic dissection. ${ }^{1,2}$

Case report: 53-year-old patient without previous medical history reports to the hospital because of shortness of breath and occasional chest tightness, which he notices for the past two months. Clinically there is audible diastolic murmur next to the left edge of sternum and peripheral congestion. Laboratory tests excluded acute coronary syndrome, NT-proBNP was elevated at $2013 \mathrm{ng} / \mathrm{L}$. Echocardiographically we verified significant dilated ascending aorta size $(75-84-82-80 \mathrm{~mm}$ ) with consequently severe aortic regurgitation (AR PHT $112 \mathrm{~ms}$ ) and dilated left ventricle with reduced systolic function (LVEF 36\%). CT angiography excluded dissection and confirmed echocardiographic test findings of ascending aorta. Coronary angiography was performed, epicardial blood vessels were without stenosis. This patient was presented to cardiac surgeon and upon completion of preoperative assessment, Bentall procedure was performed - reconstruction of ascending aorta and a replacement of the aortic valve with a composite graft. Postoperative progress went without complications, and the subsequent pathohistological test result was unremarkable.

Conclusion: Our case presentation is interesting and unusual because of the clinical presentation of the gigantically dilated aorta which is often manifested by dissection. Here it was camouflaged by clinical picture of the initial heart failure which in its basis had critical phase of the underlying disease. These findings should be taken into consideration and carefully looked into in everyday medical practice.
RECEIVED:

February 28, 2019

ACCEPTED:

March 24, 2019

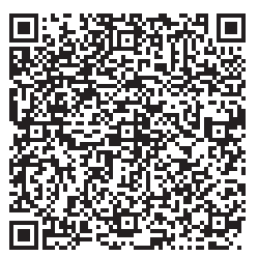

$\square$ Cardiologia Croatica 2019:14(3-4):86.
10. hrvatski dvogodišnji ehokardiografski kongres s međunarodnim sudjelovanjem $10^{\text {th }}$ Croatian Biennial Echocardiography Congress with International Participation Poreč, 16. do 18.5.2019.

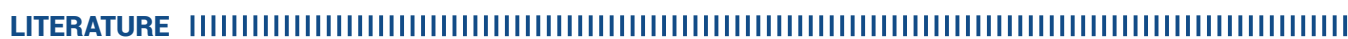

1. Elefteriades JA. Natural history of thoracic aortic aneurysms: indications for surgery, and surgical versus nonsurgical risks. Ann Thorac Surg. 2002 Nov;74(5):S1877-80; discussion S1892-8. https://doi.org/10.1016/S0003-4975(02)04147-4

2. Mathur A, Mohan V, Ameta D, Gaurav B, Haranahalli P. Aortic aneurysm. J Transl Int Med. 2016 Apr 1;4 (1):35-41. https://doi.org/10.1515/jtim-2016-0008 